\title{
The Evaluation of Physical Dimension on the Design of Campus Buildings towards Resilience Initiative at the University of Malaya
}

\author{
Salomé Talebloo ${ }^{1,}$ Anuar Alias ${ }^{2, *}$ \\ ${ }^{1}$ University of Tehran, School of Architecture college of Fine Arts, Center of Excellence in Architectural \\ Technology (CEAT), Tehran, Iran \\ ${ }^{2}$ Centre for Building, Construction and Tropical Architecture, Faculty of Built Environment, Universiti \\ Malaya, 50603 Kuala Lumpur \\ ${ }^{2}$ Department of Real Estate, Faculty of Built Environment, Universiti Malaya, 50603 Kuala Lumpur \\ *anuar_a@um.edu.my
}

Over the last few decades, the concept of resilience has received a great deal of attention in urban contexts. Universities are a hub of learning in the urban system, with diverse stakeholders facing various risks. As a result, to mitigate the adverse effects of any calamity, it is in the university's best interest to embed resilience components. There are still few studies on campus that address the concept of resilience. As a result, the purpose of this descriptive-analytical study is to create a practical framework for examining factors that specifically impact the physical characteristics of campus resilience, with the University of Malaya as a case study. The physical dimension measurement tools are developed through a systematic review of the literature and validated through expert interviews. The AHP method is used to weight 12 indicators to assess U.M. resiliency through four different buildings. According to the findings, each building has a different level of resilience index ranging from 0.30 to 0.80 , and building characteristics play a critical role in U.M. resiliency. As a result, the final index reveals that U.M. has a moderate level of resilience.

Keywords: Campus Resiliency, Physical dimension, Physical-structure Resiliency, Design, University of Malaya 


\section{INTRODUCTION}

Since the 1960s, urban planning and management have made considerable strides in their consideration of resiliency (Sharifi \& Yamagata 2016, 5). When urban development and natural disasters overlap, an unavoidable result is the severity of the impact on the urban community (Kavian, 2011, 4). To build resilient cities, the United Nations calls for the implementation of infrastructure adaptations in the event of possible risks. Integrating resilience approaches into the Hyogo Act and the DRR 2015-2030 aims to increase the capacity of society to accommodate better and manage change (UNISDR 2010).

Considering cities as complex systems, this study expands on the notion of resilience in campus regions as a knowledge hub and key position to characterise campus management's ability to prepare for and respond to hazards effectively. Universities are often a dynamic structure with a wide range of activities and stakeholders (e.g. students, alumni, lecturers, staff, administrators, community groups, visitors). Any imbalance or unanticipated change on campus causes problems and disruptions to its functions. Thus, for the benefit of the university's stakeholders, notably students' wellbeing and pleasure, it is critical to strengthen the educational system's capacity to adapt to and prepare for such enemies (Weerasinghe et al., 2018; Putri et al. 2017). This can be accomplished by keeping the land and buildings in good shape, improving infrastructure and facilities, and identifying sensitive areas in order to use disaster recovery models in the lowest amount of time.

According to such unique characteristics of each university, we examine U.M. campus resiliency as a case study in the Southwest area of Kuala Lumpur with long-term investing in its location. U.M., one of the oldest universities in Malaysia with 922 acres, acts as a hub of education, knowledge and scientific advancement, economic productivity, socio-cultural activities throughout the state. Therefore, it can be vulnerable to climate hazards from several issues, such as physical features, density, obsolescence of buildings and infrastructures (Chang 2014), poor resource management, and lack of preparedness and recovery planning after a crisis.

The main objective of this research is to find effective aspects and elements that address the physical dimension of campus resiliency and bridge the theoretical concept of resilience by providing a practical framework to evaluate U.M. robustness. The greater the collaboration between the resilience concept and campus decisionmakers, the greater the ability to recover with an effective response to disruption. It is worth noting that, because Malaysia's climate is in the centre of tropical regions, we concentrated on the flood phenomenon. As a result, the following questions will be addressed by this research: 1) What effect do physical components have on-campus resilience performance? 2) What elements have a beneficial impact on campus resilience in dealing with potential risks? 3) What is the current state of U.M. resiliency in terms of physical dimensions?

\section{THEORITICAL FRAMEWORK}

\subsection{Concept and Definition of Resilience}

Resilience thinking has become recently widespread in all scientific issues, especially in environmental and urban studies. It is argued that the resilience concept is a new analytical dimension in disaster vocabulary, although there is still no unified definition among literature (Bujones et al. 2013) in this respect; Timmerman (1981) was probably the first one that interpreted the concept of resilience in natural hazards.

The term "resilience" was derived from the Latin word "resilire," which means "jumping back," and alludes to the "bouncing back" to the original state (Klein et al., 2003). It is also recognised as a system's ability to recover and restore efficiency following earthquakes in many circumstances (Gunderson 2012). The earliest definition of resilience was brought and used in Holling's (1973) ecological studies; resilience refers to the capacity of the stressed system to return to its original state as well as the amount of disruption that the ecosystem can absorb without radical changes and remain stable (Amaratunga and Haigh, 2011).

The notion of resilience as a process in a system (Linkov et al., 2020) cascading into a wide range of disciplines, first introduced by Holling (1973) in the ecological system, then in the social system (Adger, 2000), human and environmental systems (Carpenter, 2001), socio-ecological systems (Berkes 2003), and short-term disaster management (Bruneau, 2003). However, the resilience concept has a long history in ecology and engineering, but its function is relatively new in risk management (Liao, 2012), specifically after Hurricane Katrina in 2006. Globally, there is a sweeping change in how to cope with disaster events, the Hyogo (2005) underlines effective response during the crisis by building resilience instead of mitigating vulnerabilities. Accordingly, Gallopin (2006) defines resilience as a subset of a system's capacity to respond to disruptions by promoting creativity and learning from experience (Magurie et al., 2007). In the context of utilising the system in a practical 
direction, Rezaie (2012) explains change is inevitable in every sphere of life. If changes are supposed to pose a threat, promoting a system directing to pre-crisis situations is normal. But if changes are thriving to new developments, it is desirable to focus more on creative and dynamic learning to adapt to new conditions. However, most definitions of resilience vary in scope Table 1. Due to the diverse perspectives and viewpoints of literature (Rose, 2009; McEntire et al., 2002), this study defines resilience as the ability of a system to respond promptly and adapt effectively to changes. On balance, the definition of resilience by Carpenter et al. (2001) is accepted by the majority of scholars as a comprehensive definition. Accordingly, resilience defines the amount of disruption that a system can absorb to withstand in the pre-crisis condition and the capacity of a strategy to self-organise, adapt and learn from lessons (Rafeian et al., 2011; Rezaie, 2016).

\subsection{Dimension of Resillience}

As mentioned above, achieving a unified definition of resilience and operating a comprehensive framework to quantify resilience can be challenging due to the multi-dimensional characteristics of resilience. The study conducted by Cutter et al. (2011) determines the condition of community resilience through six dimensions of ecological, social, economic, institution, infrastructure, and social capital. Bruneau et al. (2003) provide the framework of quantitative measures of resilience presenting four dimensions of technical, organisational, social, and economical. In a different perspective to reinforce flexibility and develop damaged functions, Kloc (2010) examines the tolerance of stress and shock before changing in a system as a key driver in resilience. In the study of the concept of «Resiliency» and its indicators Rezaei (2016) highlights Carpenter's view as a comprehensive approach and introduces four dimensions of social, economic, institutional, and physical resilience. Hence, this study, regardless of four dimensions of resilience, addresses the physical dimension to identify the main factors that assess the level of campus resiliency Figure 1 .

\subsection{The Concept of Resilience in the Urban Society}

Despite a strong foundation in ecological science, resilience is gaining traction in urban design and management. The incorporation of the concept of resilience in sustainable development is undeniable when there is a need to maintain and meet current needs without depleting resources for future generations to ensure the quality of life and wellbeing of the community (McEntire et al., 2002, 47; Chelleri et al., 2012). As a result, Cutter et al. (2008) define resilience as the ability of urban systems to adapt efficiently and to recover quickly from aftershocks.

The performance of urban resilience facing a crisis arises from two attributes of preparedness and responsiveness (Cheshmehzangi, 2020). In this respect, he underlines the inherent quality of action in typical situations to assess the community's preparedness and the adaptive and flexible response to cope with the disruption.

Table 1: Selected definition of resilience

\begin{tabular}{|ll|}
\hline \multicolumn{1}{|c|}{ Author } & \multicolumn{1}{c|}{ Definition } \\
\hline $\begin{array}{l}\text { Miletti } \\
1999\end{array}$ & $\begin{array}{l}\text { Local resiliency concerning disasters means that a locale can withstand an extreme natural event } \\
\text { without suffering devastating losses, damage, diminished productivity, or quality of life without a } \\
\text { large amount of assistance from outside the community }\end{array}$ \\
\hline $\begin{array}{l}\text { Carpenter } \\
\text { et.al 2001 }\end{array}$ & $\begin{array}{l}\text { Amount of disturbance a system can absorb and remain within a domain of attraction; capacity of } \\
\text { learning and adaptation; the degree of which the system is capable of self-organising }\end{array}$ \\
\hline $\begin{array}{l}\text { Folke } \\
\text { 2002 }\end{array}$ & $\begin{array}{l}\text { We use the concept of resilience as a capacity to buffer change, learn and develop, as a } \\
\text { framework for understanding how to sustain and enhance adaptive ability in a complex world of } \\
\text { rapid transformations }\end{array}$ \\
\hline $\begin{array}{l}\text { UNISDR } \\
\text { The capacity of a system, community, or society potentially exposed to hazards to adapt by } \\
\text { resisting or changing to reach and maintain an acceptable level of functioning and structure is } \\
\text { determined by the degree to which the social system is capable of organising itself to increase this } \\
\text { capacity for learning from past disasters for better future protection and to improve risk reduction } \\
\text { measures }\end{array}$ \\
\hline
\end{tabular}




\begin{tabular}{|c|c|}
\hline $\begin{array}{l}\text { Bruneau et } \\
\text { al. } 2003\end{array}$ & $\begin{array}{l}\text { Resilience reflects a concern for improving the capacity of physical and human systems to } \\
\text { respond to and recover from extreme events. Resilient systems reduce the probabilities of failure; } \\
\text { the consequences of failure-such as deaths and injuries, physical damage, and adverse economic } \\
\text { and social effects; and the time for recovery }\end{array}$ \\
\hline $\begin{array}{l}\text { Adger et.al } \\
2005\end{array}$ & The capacity of the ecological system to absorb disturbance to maintain feedbacks and processes \\
\hline $\begin{array}{l}\text { Manyena } \\
2006\end{array}$ & $\begin{array}{l}\text { Disaster resilience could be viewed as the intrinsic capacity of a system, community, or society } \\
\text { predisposed to a shock or stress to adapt and survive by changing its nonessential attributes and } \\
\text { rebuilding itself }\end{array}$ \\
\hline $\begin{array}{l}\text { Davis } \\
2006\end{array}$ & $\begin{array}{l}\text { The ability of communities, physical, social, political, economic systems and resistance to } \\
\text { accident shocks that can return quickly and accept the future risk. }\end{array}$ \\
\hline $\begin{array}{l}\text { Cutter et.al } \\
2010\end{array}$ & $\begin{array}{l}\text { Capacity to absorb the basic function during accidents and ability to return to equilibrium after a } \\
\text { disturbance }\end{array}$ \\
\hline $\begin{array}{l}\text { Moberg et } \\
\text { al. } 2011\end{array}$ & $\begin{array}{l}\text { Emphasising knowledge and education, in other words, the ability to gain experience from } \\
\text { disorders to optimal use for the future }\end{array}$ \\
\hline $\begin{array}{l}\text { Boon et.al } \\
2012\end{array}$ & $\begin{array}{l}\text { Resilience is a dynamic process and happens through people who adapt and respond to the } \\
\text { change. This process allows them to maintain their performance }\end{array}$ \\
\hline $\begin{array}{l}\text { Kärrholm } \\
2014\end{array}$ & $\begin{array}{l}\text { The severity of an organisation can absorb before system structure change to different function } \\
\text { through variables that control its function }\end{array}$ \\
\hline $\begin{array}{l}\text { Kutum and } \\
\text { AlJaberi } \\
2015\end{array}$ & $\begin{array}{l}\text { The capacity of the ecological system to absorb disturbances and maintain a stable process } \\
\text { referred to the inherent of a system }\end{array}$ \\
\hline
\end{tabular}

In terms of building resilient communities, Davis and Izadkhah (2006) focus on the performance of the societies during and after disruption, creating adaptable opportunities for quick recovery from the shocks, and learning from the experiences (Evans, 2011).

Therefore, resilient communities need to develop the ability of prediction, preparation, and immediate response in times of need for future development (Mayunga, 2007). In comparison between two high and low resilient communities, Zhang (2006) determines that a highly resilient community experienced less degree of the adversary impacts, while in low resilient society, it is damaged more and needs a longer time to bounce back to the normal state. Hence, the ability to react in the shortest possible time (Colten et al., 2008) is considered a key factor in resilient societies.

Table 2 : Resilience Dimension and Components

\begin{tabular}{|cll|}
\hline Resilience Dimension & \multicolumn{1}{|c|}{ Characteristic } & \multicolumn{1}{c|}{ Indicators } \\
\hline Social & The capacity of communities to respond & $\begin{array}{l}\text { knowledge and awareness, creativity } \\
\text { and innovation, adaptability, }\end{array}$ \\
Godschalk, 2003 & and maintain their original function as a & vulnerability, cultural services, \\
Walker \& Salt, 2006 & reduction of violence, insecurity, \\
Suárez et al., 2016 & ande. The dynamic system of & and urban crime, capacity, diversity \\
& communities needs to develop & competence, and abilities \\
& collaboration between people, & \\
& institutions, and the environment and & \\
& reduce disruption. & \\
\hline
\end{tabular}




\begin{tabular}{|c|c|c|}
\hline $\begin{array}{l}\text { Economic } \\
\text { Ernstson, et al } 2010\end{array}$ & $\begin{array}{l}\text { The capacity of economic life to change } \\
\text { by enabling communities to respond } \\
\text { and adapt in the face of disturbance to } \\
\text { reduce damages from disasters. }\end{array}$ & $\begin{array}{l}\text { Livelihoods and viability, urban } \\
\text { economic strategies and policies, } \\
\text { communication, wealth and } \\
\text { employment, insurance, individual's } \\
\text { income, economic diversity }\end{array}$ \\
\hline $\begin{array}{c}\text { Institutional } \\
\text { Ernstson, et al } 2010\end{array}$ & $\begin{array}{l}\text { The capacity of a system for } \\
\text { collaboration between organisations and } \\
\text { improving the social system with } \\
\text { learning from experience and reducing } \\
\text { risk }\end{array}$ & $\begin{array}{l}\text { Institutional skills and structures, } \\
\text { decision-making policies, integrated } \\
\text { management, diversity of } \\
\text { organisational levels, adaptability or } \\
\text { adaptation capacity, the timely } \\
\text { response speed, }\end{array}$ \\
\hline $\begin{array}{l}\text { Environmental/Physical } \\
\text { Walker \& Salt, } 2006 \\
\text { Godschalk, 2003 } \\
\text { The Rockefeller } \\
\text { Foundation, 2014 } \\
\text { Sharifi \& Yamagata, } 2016\end{array}$ & $\begin{array}{l}\text { The capacity of returning after a crisis } \\
\text { like shelters, vacant or rental residual } \\
\text { units, health and safety facilities. } \\
\text { Assessing the community reaction and } \\
\text { the proportion of individual assets that } \\
\text { might be vulnerable to permanent } \\
\text { damages and possible economic losses. }\end{array}$ & $\begin{array}{l}\text { Infrastructures, diversity, } \\
\text { connectivity, the number of urban } \\
\text { arteries, land use, } \\
\text { climate and soil health, adaptive } \\
\text { design and transportation, the witch } \\
\text { capacity of shelters, green areas }\end{array}$ \\
\hline
\end{tabular}

Muller et al. (2011) present a realistic methodology for optimising local planning in the eastern portion of San Diego, Chile, by utilising indigenous data and identifying susceptible regions against the flood phenomenon. Meanwhile, in the study of evaluating buildings' resilience to floods, Naumann et al. (2011) measure the vulnerability of the building structure by constructing aspects that improve the performance of structures through the disaster. The adaptability of indicators can be used in various threats depending on their geographical location (Kappas et al., 2012; Williamson, 2015; Dai et al., 2002). Suarez et al. (2016) present the framework for measuring urban resilience and its function in 50 Spanish cities as a case study, showing that most cities are far from resilient. They emphasise the emergence of multifunctional open space inside the density of urban fabric that can improve the urban function through evacuation and preserve resources (Tiilo, 2011; Zivkovic et al., 2019; Brouwer and Van, 2004). Eventually, merging resilience approaches with development plans and considering resilience as a goal arises from natural disasters (Khailani, 2013; Proverbs, 2017; Evans, 2011) to build a more adaptable and flexible community to withstand change

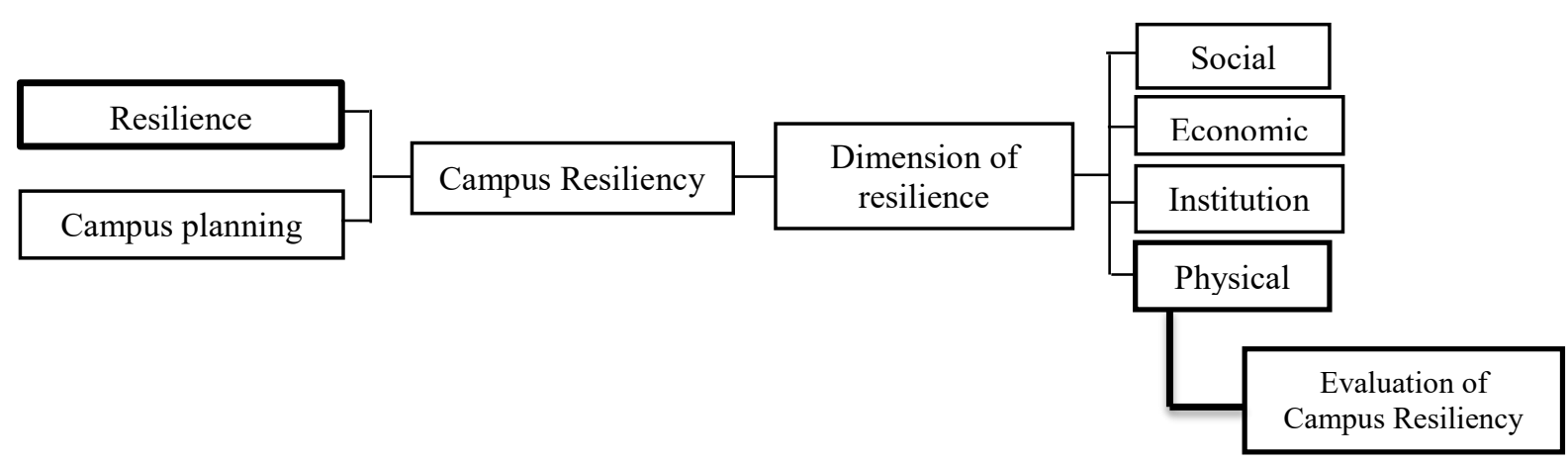

Figure 1 : Diagram of the research Conceptual model

\subsection{The Physical Feature of Urban Space}

The process of urban resilience and sustainable development has lately influenced cities. In this context, civic systems are defined by three major factors: structure, human, and human-structure interaction. When it comes to the structural attribute, any physical adversity has a detrimental impact on resilience. As a result, the field of infrastructure and the built environment, such as key arteries, building durability, building age, land use, transportation network, and accessibility to emergency and open-space, all play an essential part in the physical dimension of resilience (Cutter et al., 2011; Behtash et al., 2013; Pregnolato et al., 2017).

Meanwhile, the Oregon university draft in 2017 emphasised the preparedness of educational institutions to achieve a safer and more resilient 
campus now and in the future. Accordingly, we examine campus resiliency from the perspective of physical/structural dimensions. In this way, building a resilient campus as an orchestra of educational, social-cultural, economic, and physical activities can enhance the performance of educational hubs in urban systems on the one hand and optimise the physical potential of the urban system, on other. It is worth noting that the university buildings as durable assets with almost 100 -year or more provide a suitable environment for learning and education. Therefore, lowdurable buildings could be more vulnerable to dealing with the crisis (Latif et al., 2015; Rezaei, 2010). Kenny (2016) in his book, provides a framework for campus operational functions by enhancing the physical building features to be more resilient that guarantee students' educational lives. The following Table 3 utilises the physical characteristics of the urban fabric associated with the campus space applied in other institutions (Wamsler, 2014).

Table 3:. The physical Feature of the Campus area

\begin{tabular}{ll}
$\begin{array}{c}\text { Physical/Spatial } \\
\text { Features }\end{array}$ & \multicolumn{1}{c}{ Distinctive Campus Characteristics } \\
\hline Location & $\begin{array}{l}\text { Implying the relationship between each biological center and its environment on a } \\
\text { wider scale }\end{array}$ \\
\hline Natural bed & $\begin{array}{l}\text { Placing of hubs on the natural bed as well as topography, vegetation, and the quality } \\
\text { of the land that the buildings are located }\end{array}$ \\
\hline $\begin{array}{l}\text { Campus } \\
\text { structure }\end{array}$ & $\begin{array}{l}\text { It is very important the logical positioning and relationship between the main } \\
\text { components in balancing the campus area }\end{array}$ \\
\hline Campus texture & $\begin{array}{l}\text { The physical composition of university components at the surface and altitude. } \\
\text { Primarily, density is one of the main indexes based on the functional positioning on } \\
\text { the land, height, and their relation to open space, as well as activity volume and the } \\
\text { number of units in the piece of land. In addition, the building type (form, architectural } \\
\text { details, and materials) is considered as another indicator at this part. }\end{array}$ \\
\hline Street network & Creating a network that connects people and vehicles in the academic environment \\
\hline Open space & $\begin{array}{l}\text { It is used as a balancing space in the campus area, including natural and artificial } \\
\text { elements }\end{array}$ \\
\hline Land use & \begin{tabular}{l} 
It is identified the spatial distribution of activities within the university area \\
\hline It is considered to the type of design and materials in the shaping of academic form
\end{tabular} \\
\hline
\end{tabular}

\section{RESEARCH METHOD}

Examining campus resilience necessitates complicated thinking and methodologies similar to those used to study urban resilience. Therefore providing a much more detailed explanation of the case study, it is necessary to identify characteristics that specifically affect the physical dimension to assess the level of campus resilience. In this regard, the choice of indicators in a resilience study should be guided by two criteria. 1) rationale based on resilience literature; 2) availability of qualitative data (Rezaei 2012). This study is a descriptive-analytic study that uses Cutter's approach's place-based model to highlight the physical dimension of resiliency. One of the most significant obstacles of this study is the lack of a uniform definition and fixed variables affecting the physical dimension to match the potential danger of flooding. Being previously said, cities, as a complex and dependant system, are subject to both natural and man-made disasters. As a result, we look at research that assesses the level of resilience in urban systems, specifically campus areas., to extract the most appropriate indicators through the physical dimension, a systematic evaluation of library studies and databases from Science Direct, Google Scholar, Springer, and SID and indepth research. In-depth conversations with specialists in urban planning and development validate the measurement techniques..

This study aims to identify the most influential factors to evaluate campus resilience through the physical dimension. Accordingly, the importance of selected indicators is ranked under the vulnerability level to develop the hierarchical tree by the AHP (Analytical Hierarchy Process)

81 Journal of Design and Built Environment, Vol 21(2) 76-91, August $2021 \quad$ Alias. et al. 
method to provide the consistent judgment of the pairwise comparison. The measurement tools consist of both quantitative and qualitative criteria, which is the main advantage of the AHP method. According to the case study, four buildings were selected randomly by the sampling method and completed the data from the field study to adjust most indigenous variables.

To determine the weight and the importance of each factor descriptively through selected buildings, the pairwise comparison has been applied in the Expert Choice Software.

The final findings are presented as an index of the maximum and minimum method, with a number (1) representing the maximum numerical value of each domain and zero $(0)$ defining the minimum. Calculated numbers are displayed in five Likert scales to show various index information. Finally, the ultimate assessment of U.M. resilience by having the integration of indices from each indication.

Table 4 : Converting a Numerical Value to Ranking Colors

\begin{tabular}{|c|c|c|}
\hline Color & Normalise rate & Normalise index \\
\hline & Very low & $0 \_0.2$ \\
\hline & Low & $0.2 \_0.4$ \\
\hline & Moderate & $0.4 \_0.6$ \\
\hline & High & $0.6 \_0.8$ \\
\hline & Very high & $0.8 \_1$ \\
\hline
\end{tabular}

\section{CASE STUDY}

The University of Malaya is well-known as the oldest Malaysian university. It is considered a public research university, located as a cornerstone in the Southwest area of Kuala Lumpur (capital of Malaysia) with 922 acres. The University of Malaya roots its name from the term "Malaya", known as a country name. The University of Malaya has one campus with 512 blocks in its campus area with 11,971,503.55 square feet. It is located between the Southeast of K.L. and east of the Petaling Jaya and bordered by five entrances and surrounded by 79 floristries and the Pantai river at the centre. The maintenance of the green area allows some space for future extension

According to the Malaysian Meteorological Department (MMD), extreme rainfall associated with flood risk is increasing over the last few years that impact most parts of the country. Thus, severe rain has led to the corresponding increase in landslides that is a common factor in Malaysia and overflowing with water on the road network and water penetration into exterior building materials has generally detrimental effects on urban activities. The wide range of people with diverse activity on-campus areas includes students, lecturers, and staff in various parts, either full-time or part-time. It could, therefore, be challenging to achieve a precise estimate of the campus population, despite the variability of the population daily. Since the campus includes a great variety of buildings with different characteristics, we examine the U.M. resiliency through randomly selected buildings, including the Faculty of Built Environment (FAB), Chancellery Building, Dewan Tunku Canselor (DTC), and 12th Residential College 


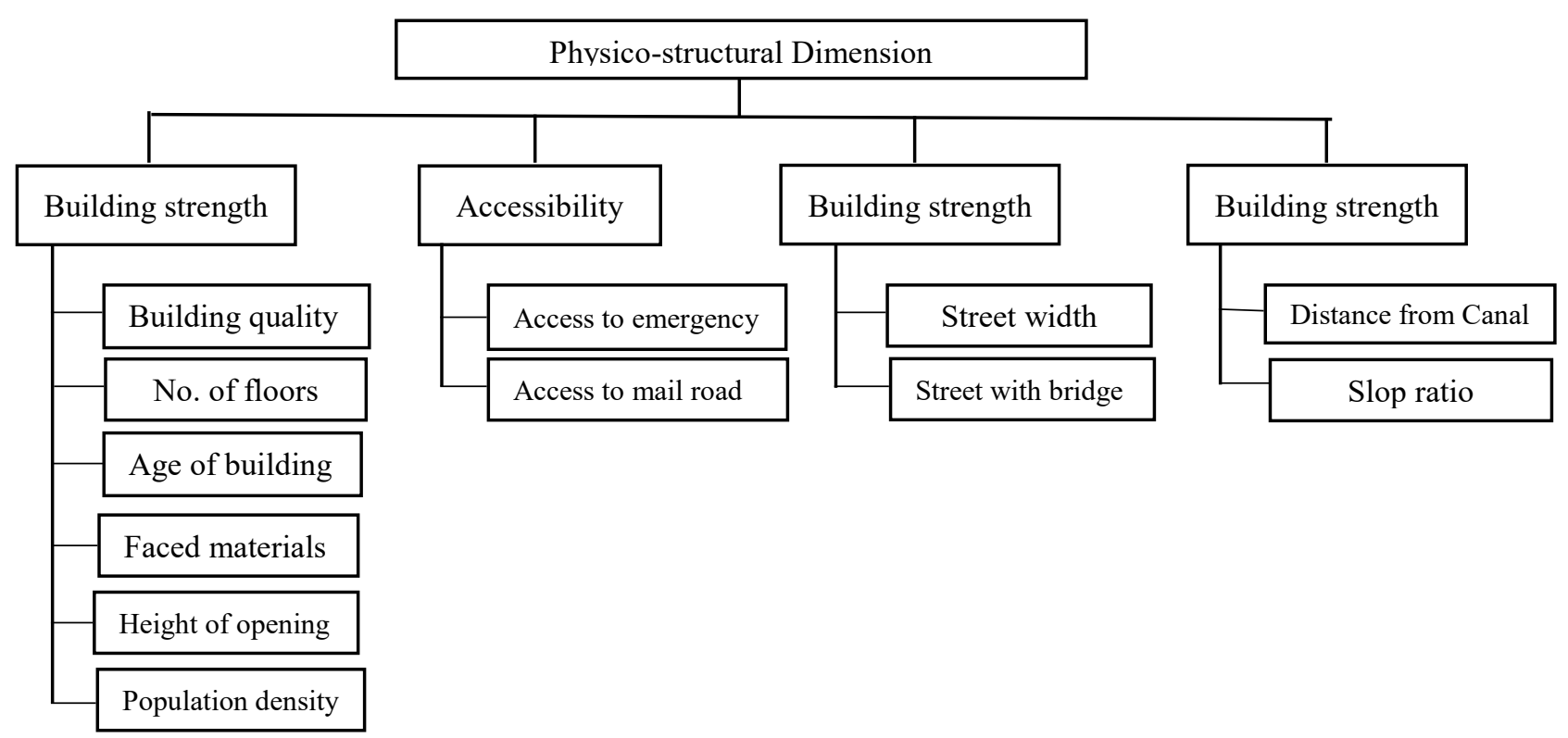

Figure 2: AHP tree for Evaluating the Physical Dimension of Resilience.

Criteria are structured into three levels. Level I indicate the dimension of the evaluation for campus resiliency. Level II presents main criteria that have been identified according to the physical dimension, and level III, the criteria in level II are broken into detailed elements.
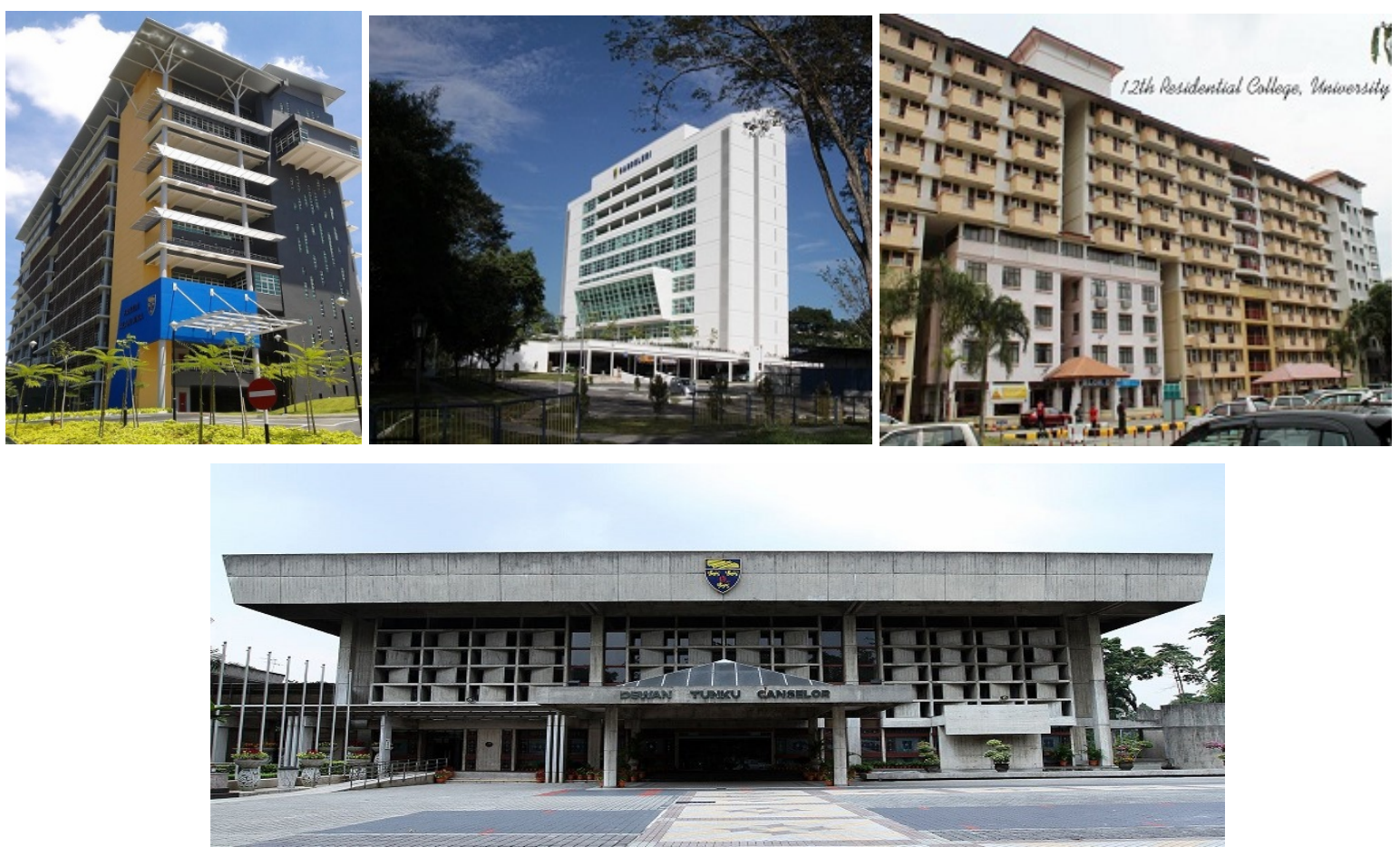

Figure 3: Selected building \& its functions: FAB (education), Chancellery Building (administrative), 12th College (residential), DTC (cultural) 


\section{SUMMARY OF FINDING}

The aim of this study to identify factors based upon the relevancy and availability apply for developing a practical framework to examine the physical dimension of campus resiliency. First, we delve into the systematic review to create the items pool of 48 indicators and reduce it to 12 hands due to some similarity between entities that may make the exact result or impact on the level of resilience. Eventually, selected factors were validated by the experts' panel and divided into four criteria of Building characteristics, accessibility, street network, and ground-bed profile, and 12 subcriteria.

It can be said that each factor has a different degree of vulnerability associated with the level of resiliency (Appendix A).

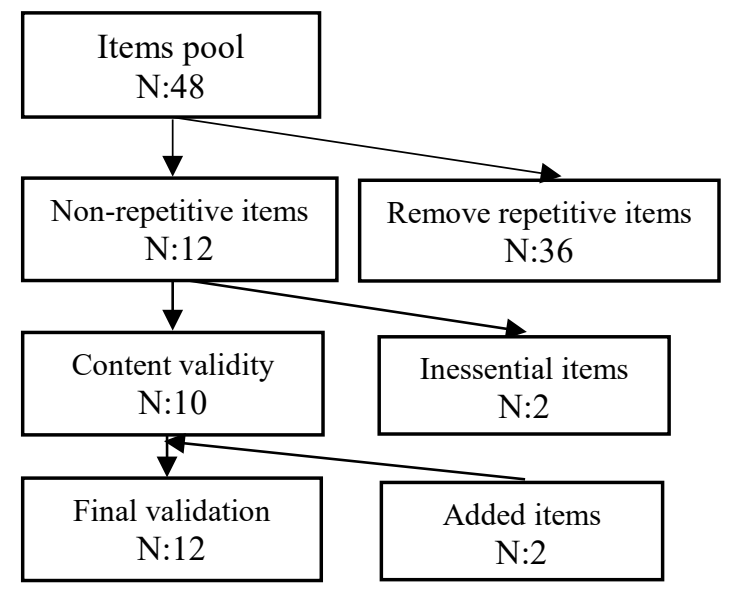

Figure 4 : The Process of Selecting Criteria

For instance, when it comes to the building characteristics, the vulnerability would be increased if the height of the building is not aligned with safety and standard rules against flood risk (Kappes et al., 2012). Likewise, in Façade material which has a ositive impact on resiliency: Some materials like glass are prone to be more vulnerable to floods than concrete (Cutter et al. 2010; Shahid 2017). As demonstrated already, the measurement tools consist of quantitative and qualitative criteria, which is the main advantage of the AHP method. So, the index is examined in the ( $\mathrm{n} \times \mathrm{n})$ pairwise comparison matrix and the Expert Choice software as a development tool is applied to revise the pairwise comparison evaluated into a consistent judgment.

According to the weighing criteria, each aspect plays a different function in the level of resiliency. 7th Table As a result, the construction qualities with the highest weight (0.565) are critical in determining resilience. Following that, the dynamic and fluid network through the crisis considers the street network vital in emergency assistance. On the other hand (0.219 weight) among the sub-criteria, building quality acts as a significant driver to improve catastrophe resilience. In general, the height of the lowest aperture, the width of the roadway, and the age of the structure account for more than half of the physical dimension of resilience. The physical properties of the U.M. resilience are indicated in the second step of the examination of each index in selected buildings. It is worth noting that the U.M. resilience under the scenario of likely floods and high rainfall is the most prevalent catastrophe in Malaysia (Wong, 2014). As described in the section on the study technique, the assessment tools addressed the most efficient and relevant indexes of the physical dimension of resiliency on a campus scale. Finally, they looked at the performance of the U.M. resilience.

Table 5: The Impact of Each Indicator on Resilience

\begin{tabular}{|c|c|c|c|}
\hline Criteria & Indicators & Justification & Effect on Resilience \\
\hline \multirow{6}{*}{ Buildings Characteristics } & Building quality & Cutter et al. 2010 & Positive \\
\hline & No. of floors & Normandin et al., 2010 & Positive \\
\hline & Building age & Cutter et al., 2010 & Positive \\
\hline & Façade materials & Lisø et al., 2003 & Positive \\
\hline & Height of lowest opening & Kappes et al., 2012 & Positive \\
\hline & Population density & Rezaei, 2010 & Negative \\
\hline
\end{tabular}


Access to emergency

Accessibility

Street network

Ground-bed profile

Access to the main road
Street width
Passage with bridge
Distance from drainage

canal Slope ratio
Asadzadeh et al. 2015

Rezaei, 2010

Sharifnia, 2012

Pashapour, 2016

Kappes et al. 2012

Rezaei 2010
Positive

Positive

Positive

Negative

Positive

Negative
It is worth reminding that the U.M. resilience applied under the scenario of probable floods and heavy rainfall are the most common disasters in Malaysia (Wong, 2014). As mentioned in the research method section, the assessment tools addressed the most efficient and appropriate indexes of the physical dimension of resiliency on a campus scale. Eventually, they examined the performance of the U.M. resilience. In this way, the final index shows that buildings are located at different levels of resilience Table 9, and the FAB has the highest value of the index 9 out of 12 indicators than the other three buildings. This means it is located in the most favourable resilience condition compared to the 12 th College with a less favourable resilience condition. By assessing the sub-criteria of the height of the building opening that is considered a crucial factor in the flood phenomena, the figure for the Chancellery building is only high and situated in a favourable condition. However, the slope ratio for the Chancellery building is more than $15 \%$ (WBDG 2017). Despite the long life of DTC (more than 50-year) it is still in a more desirable condition due to the successful renovation in 2002 after fire gutted to enhance the interior structures and upgrade its quality. The street width of the U.M. generally follows the standard of the Malaysian Public Work Department (JKR) that provides suitable conditions for all buildings.

Table 6: Assessment of Selected Building Condition

\begin{tabular}{|l|c|c|c|c|}
\hline & FAB & Chancellery & DTC & 12th College \\
\hline Building quality & New & New & Renovated & Maintained \\
\hline No. of floors & 11 & 9 & 2 & 10 \\
\hline Façade material & Concrete/ Plaster & Brick/Glass & Concrete & Brick/ Plaster \\
\hline Height of opening & $<60 \mathrm{~cm}$ & $>60 \mathrm{~cm}$ & $>60 \mathrm{~cm}$ & $10-20 \mathrm{Y}$ \\
\hline Building age & $1-10 \mathrm{Y}$ & $1-10 \mathrm{Y}$ & Up to $50 \mathrm{Y}$ & More than 200 \\
\hline Population density & $100-150$ & Until 100 & More than 200 & Low access \\
\hline Access to emergency & High access & Moderate access & Moderate access & Low $750 \mathrm{~m}$ \\
\hline Access to the road & Moderate $500 \mathrm{~m}$ & High $100 \mathrm{~m}$ & High $100 \mathrm{~m}$ & suitable \\
\hline Street width & Moderately suitable & suitable & suitable & With bridge \\
\hline Connectivity type & Without bridge & With bridge & Without bridge & \\
\hline
\end{tabular}

The assessment of selected buildings arose from the field studies and the Department of Development \& Assets Maintenance (JPPHB) database 
Table 7: The Total Condition of Selected Buildings of Resiliency

\begin{tabular}{|l|c|c|c|c|c|}
\hline & $\begin{array}{c}\text { Building } \\
\text { characteristic }\end{array}$ & Accessibility & Street network & $\begin{array}{c}\text { Ground- bed } \\
\text { profile }\end{array}$ & Resiliency \\
\hline FAB & 0.882 & 0.685 & 0.750 & 1.000 & 0.84 \\
\hline Chancellery & 0.807 & 0.799 & 0.687 & 0.224 & 0.63 \\
\hline DTC & 0.416 & 0.766 & 0.746 & 0.480 & 0.60 \\
\hline 12th College & 0.383 & 0.245 & 0.406 & 0.189 & 0.30 \\
\hline
\end{tabular}

\section{DISCUSSION AND CONCLUSION}

Despite extensive research on the concept of urban resilience in recent years, only a few studies on campus resilience have taken place. As a result, this study evaluates the level of campus resiliency at U.M. as one of Malaysia's oldest universities as a case study. The academic space typically includes various buildings with varying uses and characteristics that are susceptible to disasters. The physical dimension of campus resiliency is connected with structural factors such as building durability, roadway network, and accessibility. As a result, to assess the level of vulnerability of the physical size and develop a framework that addresses the main drivers of campus resilience, we adopt the framework of Cutter et al. (2010)'s place-based model to the unique characteristics of the campus area and the availability of the selected factors. It is worth noting that the framework can be used in other Malaysian universities to conduct a comparison study.

This study highlights the most relevant and essential items for evaluating campus resilience in the physical domain in the practical implementation for universities' decision-makers.

As a result of the systematic review of literature, 48 articles were extracted, and 12 items were ultimately chosen to be included in the final index. The assessment of criteria reveals that the structure element (building attributes) has an essential value, while the spatial part has the least (accessibility). It could be because there is no explicit action to reduce risk in the accessibility section, which requires more research. Building features through selected buildings demonstrate that buildings serve various roles and purposes on campus. Only two buildings (FAB and Chancellery Building) have a less than ten-yearold structure and in good condition. On the other hand, DTC is a more than 50-year-old building in a more desirable state of resiliency, implying that if the building's standards are upgraded and adapted to catastrophes, the vulnerability can be minimised. On the other hand, the less favourable condition of 12th College is influenced by three key factors of the population ratio: the location below the street level and proximately to the canal (less than 100 meters), increasing the probability of flood vulnerability mitigate the level of resiliency.

In conclusion, the building performance and location through disasters directly impact the ability of the emergency services, settling and reorganising. Their non-vulnerability, therefore, is improving the resistance of the building (absorbing capacity), and their persistence during the crisis will ensure the physical resilience of the campus (buffering capacity), which situate the U.M. campus in a moderate condition of stability. Further study is needed in other dimensions (economic, social, institution) of resilience to achieve a comprehensive result.

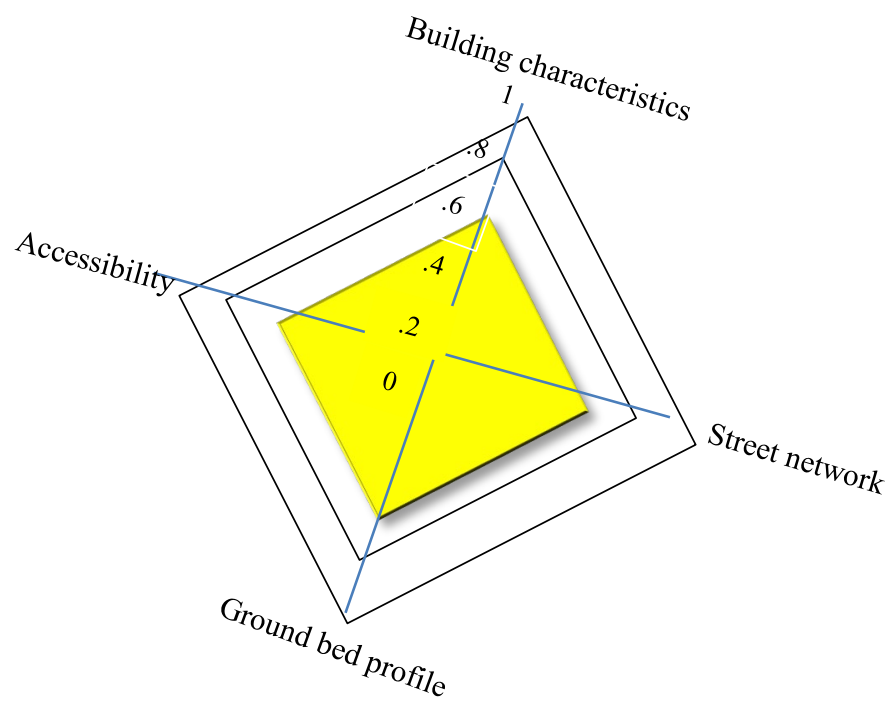

Figure 5. Average Resiliency Index at the UM: 0.58 


\section{REFERENCES}

[1] Adger, W., Hughes, T P., Folke, C., Carpenter, S. R. \& Rockstrom, J. (2005). Socio-Ecological resilience to coastal disasters. [DOI: 10.1126/ 1112122]

[2] Ahmad. F. Roslan, Z. ABD. Hamid, (2015). Strategic Framework towards Flood Resilience in Malaysia. Strategic Framework Toward flood. [DOI: 289530317]

[3] Allan, P., Bryant, M., (2012). Resilience and framework for urbanism and recovery. Journal of Landscape architecture, Vol. 6, No. 2, Pp. 34-45.

[4] Amaratunga D., Haigh, R., (2011). Postdisaster reconstruction of the built environment: rebuilding for resilience. [online]ISBN:9781444333565 [DOI: 10.1002/9781444344943]

[5] Behtash, F., Keynejad, M. A., Pirbabaie, M., Asgary, A., (2013). Evaluation and analysis of dimensions and components of Tabriz metropolis resiliency. Memari-VaShahrsazi, Vol. 18, Iss. 3, Pp. 33-42.

[6] Berke, P. \& Glavovic, B. (2012). Ecosystems and Disaster Resiliency: Contributions to a Holistic Theory of Recovery. International Journal of Mass Emergencies and Disasters, 30, 182-196

[7] Boon HJ, Millar J, Lake D, Cottrell A, King D. (2012). Recovery from disaster: resilience, adaptability, and perceptions of climate change. Published by: National Climate Change adaptation, [DOI: 978-1921609-63-3]

[8] Bujones A.K., Jaskiewicz K., Mcgirr M., Linakis L., (2013). A framework for analysing resilience in fragile and conflictaffected situations. Columbia/ SIPA. Economic and political development

[9] Bruneau, et al., (2003), A Framework to Quantitatively Assess and Enhance the Seismic Resilience of Communities, Earthquake Spectra, Vol. 4, No. 19, P.P. 733-752

[10] Brouwer, R. and van Ek R. (2004). Integrated ecological, economic and social impact assessment of alternative flood control policies in the Netherlands, Ecol. Econ., Vol. 50(1-2), Pp. 1-21.

[11] Carpenter SR, Arrow KJ, Barrett S, Biggs R, Brock WA, Crépin AS, et al. (2012). General resilience to cope with extreme events. Sustainability. Vol. 4, ISS. 12, Pp. 248-59.

[12] Chang, S. E. (2014). Infrastructure resilience to disasters. The Bridge, 44. 3641.
[13] Chelleri, L., Kunath, A., Minucci, G., Olazabal, M., (2012). Multidisciplinary perspectives on urban resilience. Workshop Report 1st edition, Published By: Centre for Climate Change. [DOI: 978-84-695-6025-9]

[14] Cheshmezangi, A., (2020). The city needs Urban resilience and city management in disruptive disease outbreak events. Springer, ISBN 978-981-15-5487-2

[15] Colten, C. and Kates, R. and Laska, S. (2008) 'Three years after Katrina: Lessons for community resilience'. Environment: Science and Policy for Sustainable Development, Vol. 3, Issue. 50, Pp. 36- 47

[16] Cutter, S. L. et al. (2008). A Place-Based Model for Understanding Community Resilience to Natural Disasters. Global Environmental Change, 18 (4), 598-606.

[17] Cutter, S. L. Burton, C. G. \& Emrich, C. T. (2010). Disaster resilience indicators for benchmarking baseline conditions. Journal of Homeland Security and Emergency Management, 7(1), 1-24.

[18] Dai, F. C., Lee, C. F., Ngai, Y. Y. (2002). Landslide risk assessment and management: an overview. Engineering Geology Journal. [DOI:10.1016/S00137952(01)00093-X] Vol. 64, Iss. 1, Pp. 6587.

[19] Davis, I. \& Izadkhah, Y. O. (2008). Tsunami early warning system (Béné et al.) and its integration within the chain of seismic safety. Disaster Prevention and Management: An International Journal, 17, 281-291.

[20] Evans J. P., (2011), resilience, ecology, and adaptation in the experimental city. Transaction of the institution of British Geographers, Vol. 36, Iss. 2, Pp. 223-237

[21] Folke, C., (2006). Resilience: the emergence of a perspective for socialecological systems analyses. Global Environmental Change, Vol. 16, No. 3, Pp. 253-267.

[22] Gallopin G.C., (2006). The linkage between vulnerability, resilience, and adaptive capacity. Global environmental change journal, Vol. 16, Pp. 293-303

[23] Godschalk, D., (2007), Urban Hazard Mitigation: Creating Resilient Cities, Natural Hazards Review, Vol. 4, No. 3, P.P. 136-143.

[24] Gunderson, L. (2009). Comparing Ecological and Human Community Resilience. CARRI Research, Report5, Oakridge: Community and Regional Resilience Institute, [online] http://www.resilientus.org/librar y/Final_Gunderson_11209_123177474 
[25] Hawkesbury-Nepean (2007). Reducing vulnerability of buildings to flood damage: Guidance on building in floodprone areas. Parramatta, Australia: Hawkesbury-Nepean Floodplain Management Steering Committee.

[26] Holling, C. S., (1973), Resilience and Stability of Ecological Systems, Annual Review of Ecology and Systematics, Vol. 1, No. 4, P.P. 1-23

[27] Kappes, M.S. Kohle, M. Keiler, M. (2012). Assessing physical vulnerability for multi-hazards using an indicator-based methodology. University of Vienna, Geomorphic Systems and Risk Research Unit. Vol. 32, No. 2, Pp, 577-590

[28] Kafle, SK. (2012). Measuring disasterresilient communities: a case study of coastal communities in Indonesia, J Bus Contin Emer Plan. Vol. 5(4), Pp.316-26.

[29] Kavian, F. (2011). 'Investigating role of land use planning in improving urban communities' resiliency against earthquake (case study: Sabzevar town)', Supervisor: Mohammad Salmani Moghaddam, dissertation of M.A degree in geography and urban planning, Faculty of geography and environmental sciences, Hakim Sabzevari University.

[30] Klein, R. J. \& F. Nicholls, Thomalla, F., (2003). Resilience to natural hazards: how useful is this concept?" Environmental Hazards, 5, 1-2, Pp. 35- 45

[31] Kloc L. (2010). Internal stress model for the pre-primary stage of low-stress creep. 15th International conference on the strength of materials, ICSMA-15 series 240012086

[32] Khaliani, D. Perera, R. (2012). Mainstreaming disaster resilience attributes in local development plans for the adaptation to climate change-induced flooding: A study based on the local plan of Shah Alam City, Malaysia. [DOI: org/10.1016/j.landusepol.2012.05.003]

[33] Latif, M., Irfan, A.M., Tahira, S., (2015). Role of resilience as a facilitator in higher education. Journal of Educational Research, Vol. 18, Iss. 2, Pp. 75-83

[34] Liao K.H, (2012). A theory on urban resilience to floods- A basis for alternative planning practices. Ecology and Society, Vol. 17, No. 4

[35] Linkov, I., Trump B. D., (2020), The Science and Practice of Resilience, https://doi.org/10.1007/978-3-030-045654

[36] Magurie B., Hagan P., (2007). Disaster and communities: understanding social resilience. The Australian Journal of Emergency Management, Vol. 22, No. 2
[37] Mayunga J. S., (2007), Understanding and Applying the Concept of Community Disaster Resilience: A Capital-based Approach: A draft Working Paper Prepared for the Summer Academy for Social Vulnerability and Resilience Building, PP. 22 - 28

[38] McEntire, D. A. et al., (2002). "A comparison of disaster paradigms: The search for a holistic policy guide"', Public Administration Review, Vol. 62, No.3. Pp. 267-281.

[39] Muller, J.; Reiter, J.; Weilad, U. (2011). "Assessment of urban vulnerability towards floods using an indicator-based approach - a case study for Santiago de Chile, Nat". Hazards Earth Syst. Sci. 11. Pp. 2107-2123.

[40] Meyer, V., Scheuer, S., and Haase, D. (2009). A multicriteria approach for flood risk mapping exemplified at the Mulde River, Germany, Nat. Hazards Journal, Vol. 48, No.1, Pp. 17-39.

[41] Mileti, D.S. (1999) Disasters by Design: A Reassessment of Natural Hazards in the United States. Washington: Joseph Henry Press.

[42] Nauman, T. Nikolowski, J. Golz, S. Schinke, R. (2011). Resilience and Resistance of Buildings and Built Structures to Flood Impacts -Approaches to Analysis and Evaluation, German Annual of Spatial Research, Pp. 89-100.

[43] Pashapour, H \& Pourakrami, M. (2017). Measurement of the urban dimensional resilience to a natural disaster (a case study of 12th district of Tehran). The Journal of Urban planning, Vol. 12, No. 4, Pp. 9851002

[44] Plodinec, M. John, Warren C. Edwards, Robin K. White, (2014). Applications of a "Whole Community" Framework for Enhancing Community or Campus Resilience, 4th International Conference on Building Resilience.

[45] Pregnolato, M., Ford, A, Sean M. Wilkinson, S. M., Dawason, R. J. (2017). The impact of flooding on road transport: A depth-disruption function. Transportation Research, Vol. 55, Pp. 6781

[46] Proverbs, D., Lamond, J., (2017). Flood Resilient Construction and Adaptation of Buildings, Oxford Research Encyclopedia of Natural Hazard Science. Pp. 1-35. [DOI: 10.1093/acre for/9780199389407.013.111]

[47] Rafieian, M. Rezaei, M., Askari, A., Parhizkar, A. Shayan, S. (2011). Conceptual explanation of resiliency and its indexing in community-based disaster 
management (CBDM), Modares Journal of Humanities 4(15): 19-41.

[48] Rezaei, M. Rafeyan, M. Hosseini, M., (2015). Measuring the urban resilience of Tehran. The Journal of Human Geography research quarterly, Vol. 47, No. 4, Pp. 609 623.

[49] Rezaei, M. Sarai, M. Bastamnia, A. (2016). Explaining and Analysing the Concept of «Resiliency» and its Indicators and Frameworks in Natural Disasters. Disaster Prevention and Management Knowledge Quarterly (DPMK), 6(1), 3246.

[50] Rose, A. \& Krausmann, E. (2013). An economic framework for the development of a resilience index for business recovery. International Journal of Disaster Risk Reduction. Vol. 5, Pp. 73-83.

[51] The Rockfeller Foundation. (2014). City NewYork. Framework Resilience City: Ove Arup \& Partners International Limited.

[52] Shahid, Sh. Hadipour, S. Wang, X. Shoarav, S. Minbans, A. Ismail, T. (2016). Impacts and adaptation to climate change in Malaysian real estate. International Journal of Climate Change Strategies and Management, Vol. 9, Iss. 1, Pp. 87 - 103.

[53] Sharifi, A. Yamagata, Y. (2018). Resilience-Oriented Urban Planning. ISBN 978-3-319- 75798-8 (eBook)

[54] Suarez, M.; Baggethun, E. G.; Benayas, J.; Tilbury, U. (2016). Towards an Urban Resilience Index: A Case Study in 50 Spanish Cities. Sustainability 2016, 8, 774. [DOI: 10.3390/su8080774]

[55] Tilio L., Murgante B., Di Trani F., Vona M., Masi A., (2011). Resilience city and seismic risk a spatial multi-criteria approach. Springer-verlag Berlin, Iss. 1, Pp. 410-422

[56] Wamsler, Ch., Brink, E., (2014). Moving beyond short-term coping and adaptation. Environment \& Urbanisation journal, Vol. 26(1), Pp. 86-111

[57] Weerasinghe, R. Lalitha S. Fernando, (2018). University facilities and student satisfaction in Sri Lanka, International Journal of Education Management, Vol 32, No. 55, Pp. 866-880

[58] Williamson, I., (2015). London's adaptation to the risk of severe weather. Published by London Assembly Environment Committee.

[59] Wong, F. M. (2014). Development of a climate change vulnerability index for Peninsular Malaysia. Research paper for Master. Environmental science. Pp. 5-1

[60] Zhang, Y. (2006). Modeling single-family housing recovery after hurricane Andrew in Miami-Dade County, FL, Ph.D. paper. Texas A\&M University. Vol. 72, Issue, 2. Pp. 5-24.

[61] Zivkovic M., Andjelkovic A., (2019), Dimensions and psychological correlates of student teacher's resilience.

[62] www.fema.gov/national-flood-insuranceprogram

[63] www.wbdg.org 
Appendix A

Ranking of the Importance of Sub-Indicators

\begin{tabular}{|c|c|c|c|c|c|}
\hline \multirow[t]{2}{*}{ Indicator } & \multirow[t]{2}{*}{ Sub-indicators } & \multicolumn{4}{|c|}{ Vulnerability level } \\
\hline & & Low & Moderate & High & Very High \\
\hline \multirow[t]{4}{*}{ Building quality } & New building & $*$ & & & \\
\hline & Renovated & & $*$ & & \\
\hline & Maintained & & & $*$ & \\
\hline & Ruined & & & & $*$ \\
\hline \multirow[t]{4}{*}{ No. of floors } & $1-3$ & $*$ & & & \\
\hline & $4-7$ & & $*$ & & \\
\hline & $8-11$ & & & $*$ & \\
\hline & Up to 12 & & & & $*$ \\
\hline \multirow[t]{4}{*}{ Building age } & $1-10$ & $*$ & & & \\
\hline & $10-20$ & & $*$ & & \\
\hline & $20-30$ & & & $*$ & \\
\hline & Up to 30 & & & & $*$ \\
\hline \multirow[t]{4}{*}{ Facade materials } & Concrete & $*$ & & & \\
\hline & Brick & & $*$ & & \\
\hline & Glass & & & $*$ & \\
\hline & Wood & & & & $*$ \\
\hline \multirow[t]{2}{*}{ Height of lowest opening } & Less than $60 \mathrm{~cm}$ & & & & $*$ \\
\hline & $60-100$ & $*$ & & & \\
\hline \multirow[t]{4}{*}{ Population density } & Until 100 people & $*$ & & & \\
\hline & $100-150$ & & $*$ & & \\
\hline & $150-200$ & & & * & \\
\hline & Up to 200 & & & & $*$ \\
\hline
\end{tabular}




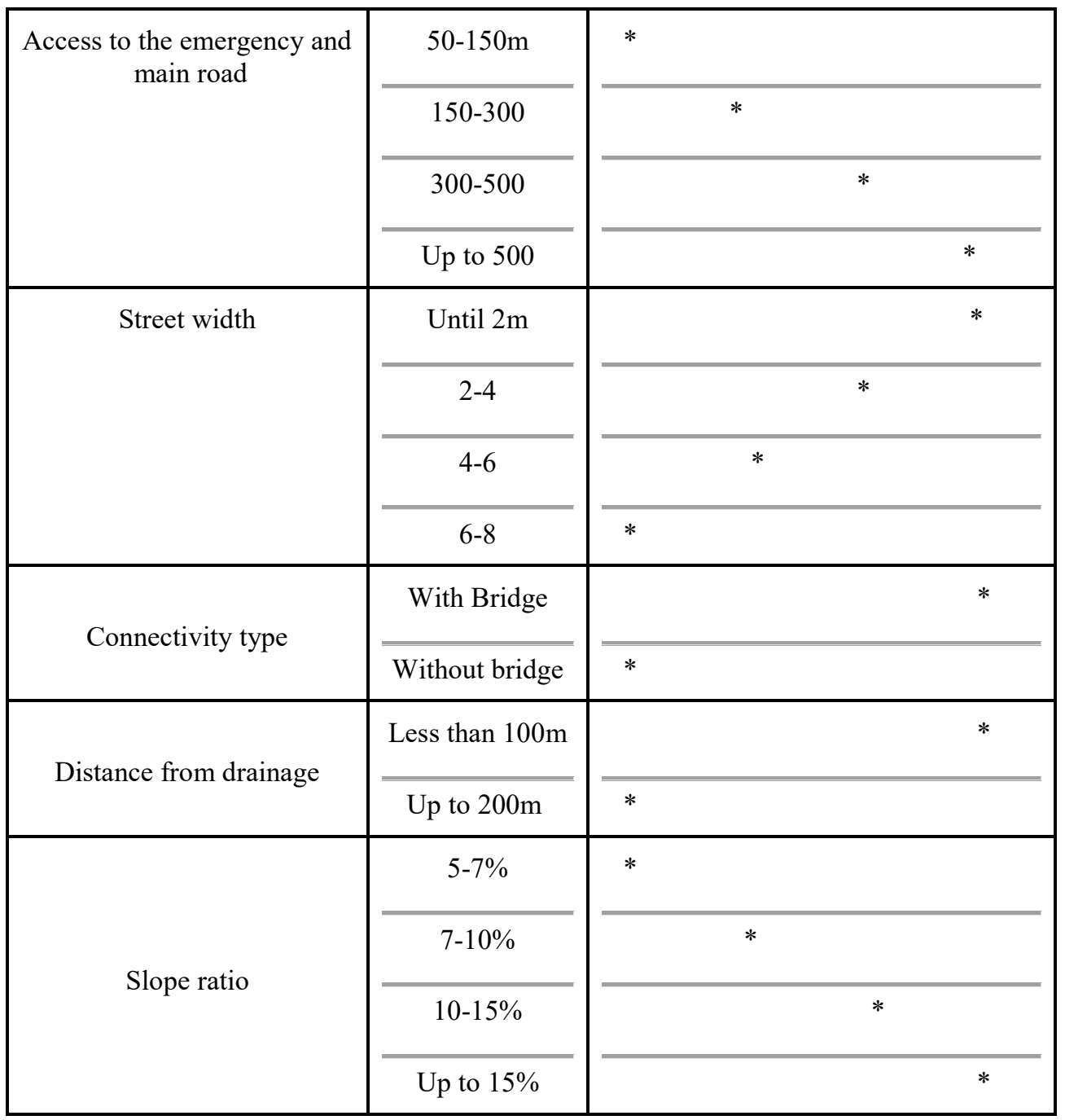

The importance of selected indicators ranking into Low, Moderate, High, and Very High categories. So high vulnerability leads to low resiliency. 